\title{
Growth and leaf epidermal response of three Sesamum indicum varieties to industrial effluent irrigation
}

\author{
A. A. AbdulRahaman*, O. M. Olaniran and F. A. Oladele \\ Applied Plant Anatomy and Wood Technology Laboratory, Department of Plant Biology, Faculty of Life Sciences, University \\ of Ilorin, Ilorin, Nigeria
}

\begin{abstract}
The effect of industrial effluents was studied with respect to growth and leaf anatomy of three Sesamum indicum varieties (NGB 00931, NGB 00937 and NGB 00939). Industrial effluents (25\%, 50\%, 75\% and 100\%) from two industries are used to irrigate the plants. Although, the control plants possessed larger leaves and longer stems than the effluent-treated plants, at lower concentration, the plant growth is relatively higher. Gradual decrease in the germination of seeds and seedling growth with increase in effluent concentration was observed. The best germination and seedling growth was observed at the $25 \%$ concentration. Leaf epidermal features (stomatal density, stomatal index, stomatal size, trichome density, tricome index, trichome size and number of epidermal cells) are more influenced in the effluent-treated plants than in the control plants from the Peace Standard Pharmaceutical Industry than in the effluent from the Global Soap $\&$ Detergent Industry. Thus the industrial effluents can be safely used for irrigation purposes with proper treatment and dilution at $25 \%$.
\end{abstract}

Keyword: Environmental pollution; germination; growth; industrial effluent; leaf anatomy; Sesamum indicum

\section{Introduction}

Environmental pollution is a matter of great concern and has been accepted as a global problem because of its adverse effects (Irshad et al., 1997). In literature various studies showed that biologists, all over the globe are monitoring the industrial effluents by chemical analysis and studying the effects on biota of affected area (Lenwood and Dennis, 2005). Industrial effluents are usually considered as undesirable for arable soil, plants, animals and human health. Many pollutants such as pesticides, oil, hydrocarbons, heavy metals and trace metals (like $\mathrm{Cr}, \mathrm{Mn}$, $\mathrm{Fe}, \mathrm{Cu}, \mathrm{Co}, \mathrm{Zn}, \mathrm{Ni}, \mathrm{As}, \mathrm{Cd}$ and $\mathrm{Pb}$ ) as well as thermal and radioactive pollutants can get into aquatic environments through direct or indirect release from industries, agriculture and households, and are allowed to spread on agricultural lands (Fathi et al., 2008). The unplanned disposal of these effluents has increased the threat of environmental pollution. Industrialization during $19^{\text {th }}$ century changed mankind's life style. New technology raised man's standard and made life more comfortable but with increasing industrial development, safe disposal of industrial waste has become more ecological challenge. The continuous increase in industries has become more sources of pollution. These industries include battery manufacturing, iron and steel, plastics, chemicals, fertilizer, textile, food and beverages, breweries, pharmaceuticals, soap, petroleum and petrochemical, automobile, tannery, paper mill and cosmetics, tobacco and paint industries.

Plants are subjected to multiple environmental pollution types. From time to time, with special reference to plant species endowed with anatomical alterations, increased chances of survival under multifarious environmental conditions have been recorded by different workers. Responses of plants to the environmental variations are complex involving deleterious or adaptive changes. These modified structural attributes in different plant body parts are of supreme importance to cope with adverse environmental conditions. Specific morpho-anatomical and physio-biochemical characteristics are the plant's adaptation in contrasting environments (Kovacic and Nikolic, 2005). The main anatomical features in green vegetation that play a key role in the process of air purification are the stomatal and the subsidiary cells. Stomatal occur on all aerial parts of the plants but they are abundant on the leaves. They may occur on both sides or only on one side of the leaf, usually the lower side.

A perusal of literature reveals that there is little information on the effect of pollutants on plant anatomy. This study 
therefore would make an attempt to assess the level of heavy metals in some industrial effluents and to investigate the effects of these effluents on the germination, growth, survival patterns and leaf anatomical adaptation of some plant species. Present study was conducted with objective to uncover species that have been blessed by nature with strong anatomical attributes of enormous potential to tackle environmental changes in the best way.

\section{Materials and methods}

\section{Source of industrial effluents and study materials}

Industrial effluents were collected from two selected industries, namely Global Soap \& Detergent Industry Ltd., Asa Dam Road and Peace Standard Pharmaceutical Industry, Adewole Industrial Estate, both in Ilorin, Kwara State, North-central, Nigeria. The effluent samples were collected in polythene container. The containers were fully sealed and stored at temperature $25-30^{\circ} \mathrm{C}$. Seeds of three sesame varieties (NGB 00931, NGB 00937 and NGB 00939) were collected from National Centre for Genetics Resource and Biotechnology, Moor Plantation, Ibadan, Oyo State, South-west, Nigeria.

\section{Physio-chemical analysis of soil and effluents}

The colour, smell and $\mathrm{pH}$ of the effluents were recorded. Later on the effluents were filtered to get the filtrate that was used in chemical analysis. In the filtrate the total soluble salts (TSS) were determined by gravimetric method. $\mathrm{pH}$ was determined using digital $\mathrm{pH}$ meter following the procedure of Schofield and Taylor (1955). Primary buffers of $\mathrm{pH} 4.01$ (phthalate), $\mathrm{pH} 6.86$ (phosphate) and $\mathrm{pH} 9.18$ (borax) and $\mathrm{pH} 0.005$ were used as references to calibrate the $\mathrm{pH}$ meter. Electrical conductivity of the effluents was determined by using digital conductivity meter. Alkalinity was determined by titration method while the total dissolved solids (TDS) were determined using gravimetric analysis.

\section{Sowing of seeds and application of pollutant}

The effluent collected from the source was considered as $100 \%$ concentration. It was diluted to $25 \%, 50 \%$ and $75 \%$ with distilled water. These dilutions of effluent along with distilled water (control) were used as the growth medium for seed germination by using standard technique (Hussain et al., 2010). There were five replicates and each replicate were with 20 seeds. Dishes were incubated for 72 hours. After the establishment of seedlings in the pots, the named pollutant were applied to each pot after making different concentrations from $0-100 \%$ as given below:

$\mathrm{T}_{0}=0 \%$ tap water (control)

$\mathrm{T}_{1}=25 \%$ pollutant $+75 \%$ tap water

$\mathrm{T}_{2}=50 \%$ pollutant $+50 \%$ tap water
$\mathrm{T}_{3}=75 \%$ pollutant $+25 \%$ tap water

$\mathrm{T}_{4}=100 \%$ pollutant

Pollutants were applied soon after sampling and carried to Botanical Garden of the University of Ilorin, Ilorin, Nigeria in order to avoid any change in characteristics and to minimize microbial activity. The irrigations were scheduled to keep the soil moisture content similar to field capacity and seedlings were irrigated at intervals of once a week to a fortnight.

\section{Macromorphometric studies}

The following macromorphological features namely leaf size and steam length were observed and measured with a metre rule. The stem height was measured starting from the base of the plant above the root to the apex of the plant. The leaf size was determined as $\mathrm{LxBxK}$. Where $\mathrm{L}=$ length, $\mathrm{B}=$ breadth, and $K=0.079$ (Franco's factor) (Franco, 1939).

\section{Leaf epidermal studies}

Leaf segments of an area 1 sq. $\mathrm{cm}$. from each specimen were cut and immersed in concentrated solution of trioxonitrate (v) acid inside glass Petri dishes for 24hrs. The macerated tissues were rinsed with clean water. With the aid of dissecting needle and forceps, upper (adaxial) and lower (abaxial) surfaces were separated.

Stomatal index which is an indicator or measure of the proportion or spread of stomatal on a leaf surface was thus calculated follows:

$\mathrm{S} . \mathrm{I}=\mathrm{S} / \mathrm{E}+\mathrm{S} \times 100$

Where $\mathrm{S}$ denotes the number of stomata for unit area and $\mathrm{E}$ denotes the number of all ordinary epidermal cells in the same unit area (Dilcher, 1974).

The mean stomatal size was determined by measuring length and breadth of guard cells multiplied by Franco's constant using an eye piece micrometer. The sample of 35 stomata was used.

$\mathrm{SS}=\mathrm{L} \times \mathrm{B} \times \mathrm{K}$

Where $\mathrm{SS}=$ stomatal size

L = Length, $\mathrm{B}=$ breadth, $\mathrm{K}=$ Franco's constant $=0.78524$ (Franco, 1939).

Stomatal density was calculated as number of stomatal per square millimeter (Obiremi and Oladele, 2001).

The trichome density was determined as the number of trichomes per square millimeter. Trichome index was determined as number of trichomes per square millimeter divided by number of trichomes plus number of epidermal cell per square millimeter multiplied by 100 . 


\section{Results and discussion}

In Table I the physico-chemical properties of the soil and industrial effluents are presented. It is these properties that influence the growth and development of the three Sesamum varieties studied. In all the three varieties and all the treatments, the control plants (T0) have better performance in terms of leaf size and stem length than the effluenttreated plants (T1 - T4) (Tables II - IIV). Readings taken at week four showed that the control plants possessed bigger leaves with $35.33 \pm 17.53 \mathrm{~cm}, \quad 18.67 \pm 8.74 \mathrm{~cm}$ and $12.33 \pm 3.18 \mathrm{~cm}$ sizes and smaller leaves with $8.67 \pm 1.76 \mathrm{~cm}$, $5.33 \pm 3.53 \mathrm{~cm}$ and $6.00 \pm 3.00 \mathrm{~cm}$ sizes in the varieties NGB 00931, NGB 00937 and NGB 00939 respectively in the Peace Standard Pharmaceutical Industry effluents. T1 $(18.67 \pm 3.38 \mathrm{~cm})$ in variety NGB00937, and T1 $(12.33 \pm 1.45 \mathrm{~cm})$ and $\mathrm{T} 2(12.00 \pm 4.16 \mathrm{~cm})$ in varieties NGB 00939 have similar leaf sizes with the control plants. Similar occurrences were observed in the Global Soap and Detergent Industry effluent-treated plants where the also control plants have the bigger leaves in varieties NGB 00931, NGB 00937 and NGB $00939(37.33 \pm 10.91 \mathrm{~cm}$, $25.33 \pm 8.99 \mathrm{~cm}$ and $29.67 \pm 4.41 \mathrm{~cm}$ respectively), and smaller leaves are in all the T4 plants $(18.33 \pm 2.60 \mathrm{~cm}, 6.67 \pm 0.67 \mathrm{~cm}$ and $11.33 \pm 1.76 \mathrm{~cm}$ respectively) (Tables II, IV and VI). The observation through the fourth week, also showed that the stem height is longer in the control plants $(33.69 \pm 3.29 \mathrm{~cm}$, $26.33 \pm 1.76 \mathrm{~cm}$ and $27.00 \pm 2.65 \mathrm{~cm}$ in varieties NGB 00931 , NGB 00937 and NGB 00939 respectively) and shorter stem in the T4 plants $(18.33 \pm 2.60 \mathrm{~cm}, 15.33 \pm 8.19 \mathrm{~cm}$ and $13.67 \pm 2.73 \mathrm{~cm}$ in varieties NGB 00931, NGB 00937 and NGB 00939 respectively) in the Peace Standard Pharmaceutical Industry effluents. The Global Soap and the Detergent Industry effluent-treated plants led to similar conditions; the control plants grown longer $(37.33 \pm 10.91 \mathrm{~cm}$, $29.67 \pm 2.91 \mathrm{~cm}$ and $31.33 \pm 1.67 \mathrm{~cm}$ in varieties NGB 00931 , NGB 00937 and NGB 00939 respectively) than the effluenttreated plants $(18.33 \pm 2.60 \mathrm{~cm}, 15.55 \mathrm{~cm}$ and $21.67 \pm 0.88 \mathrm{~cm}$ in varieties NGB 00931, NGB 00937 and NGB 00939 respectively) (Tables III, V and IIV).

There is no significant differences in the leaf size and stem height in some plants treated with effluents from the Peace Standard Pharmaceutical Industry between the controlplants and effluent-treated plants, except in week 3 between T0 and T4 plants in leaf size. Though there are no significant differences between the control and effluenttreated plants in the Global Soap and Detergent Industry. However, there are some instances of significant differences in the Global Soap and Detergent Industry effluent-treated plants. For instance, there are significant differences between $\mathrm{T} 0$ and $\mathrm{T} 4 ; \mathrm{T} 1, \mathrm{~T} 0, \mathrm{~T} 2$ - $\mathrm{T} 4$ and $\mathrm{T} 0, \mathrm{~T} 1$ and $\mathrm{T} 2$ are differed from $\mathrm{T} 3$ and $\mathrm{T} 4$ plants in week 3 in the varieties
NGB 00931 and NGB 00937 respectively, and in week between T0 and T4, T0 and T1 - T3 variety NGB 00937 plants in stem height. Also in leaf size, there are significant differences between $\mathrm{T} 0$ and $\mathrm{T} 1$ and $\mathrm{T} 2$ and $\mathrm{T} 4$ in the variety NGB 00939 (Tables II - VII).

Table I. Analysis of physico-chemical properties of soil and industrial effluents

\begin{tabular}{lccc}
\hline \multicolumn{1}{c}{ Parameters } & $\begin{array}{c}\text { Global } \\
\text { ffluent }\end{array}$ & $\begin{array}{c}\text { Peace } \\
\text { effluent }\end{array}$ & Soil \\
\hline $\mathrm{pH}$ & 11.21 & 5.68 & 5.26 \\
$\mathrm{TSS}$ & 0.71 & 0.78 & \\
$\mathrm{TDS}$ & 1.50 & 1.48 & \\
$\mathrm{TS}$ & 2.21 & 2.26 & \\
Electrical Conductivity $(\mu \mathrm{s})$ & 151 & 297 & 012 \\
$\mathrm{Alkalinity}(\mathrm{mg} / \mathrm{L})$ & 4.0 & 7.6 & \\
$\mathrm{Ca}$ & 0.04 & 0.85 & \\
$\mathrm{Mg}$ & 0.06 & 0.35 & \\
\hline TDS = total dissolved solid, TSS $=$ total soluble salt, Ca = calcium \\
$\mathrm{Mg}=$ magnesium, TS = total salt
\end{tabular}

Leaf parameters such as the stomatal size, trichome size, trichome density and number of epidermal cells are more the effluent-treated plants while the stomatal index, stomtal density and trichome index are more in the control plants in the variety NGB 00931 plants; stomatal size, trichome size, stomatal density and number of epidermal cells in effluenttreated plants while stomatal index, trichome index and trichome density are more in the control plants in the variety NGB 00937 plants; and stomatal size, trichome size and number of epidermal cells are more in the effluent-treated plants while the stomatal index, stomatal density, trichome index and trichome density are more control plants in the variety NGB 00939 plants from the Peace Standard Pharmaceutical Industry (Table VIII).

Leaf parameters such as the number of epidermal cells are more the effluent-treated plants while the stomatal size, trichome size, stomtal density, trichome index and trichome density are more in the control plants in both NGB 00931 and NGB 00937 varieties plants; and stomatal size, trichome size, stomatal density and number of epidermal cells are more in the control plants while the stomatal index and trichome index are more in the effluent-treated plants in the variety NGB 00939 plants. Meanwhile, trichome density is same in both the control and effluent-treated plants from the Global Soap and Detergent Industry (Table VIII).

The foregoing study shows that effluents from Peace Standard Pharmaceutical Industry had an inhibition effects on the growth parameters than the effluent from Global Soap $\&$ Detergent Industry. Analysis of various physicochemical 
Table II. Leaf size $(\mathrm{cm})$ of variety NGB 00931 treated with industrial effluents

\begin{tabular}{|c|c|c|c|c|c|c|c|c|}
\hline \multirow{2}{*}{$\begin{array}{l}\text { Treatment } \\
\text { /week }\end{array}$} & \multicolumn{4}{|c|}{ Peace Standard Pharmaceutical effluent } & \multicolumn{4}{|c|}{ Global Soap \& Detergent Industry effluent } \\
\hline & Week 1 & Week 2 & Week 3 & Week 4 & Week 1 & Week 2 & Week 3 & Week 4 \\
\hline T0 & $11.67 \pm 4.91^{\mathrm{a}}$ & $32.00 \pm 14.00^{\mathrm{a}}$ & $32.00 \pm 15.52^{\mathrm{a}}$ & $35.33 \pm 17.53^{\mathrm{a}}$ & $10.00 \pm 1.53^{\mathrm{a}}$ & $16.00 \pm 3.51^{\mathrm{a}}$ & $24.33 \pm 6.89^{\mathrm{a}}$ & $37.33 \pm 10.91^{\mathrm{a}}$ \\
\hline $\mathrm{T} 1$ & $10.33 \pm 2.60^{\mathrm{a}}$ & $14.67 \pm 6.67^{\mathrm{a}}$ & $15.67 \pm 10.27^{\mathrm{a}}$ & $33.33 \pm 13.33^{\mathrm{a}}$ & $10.33 \pm 0.88^{\mathrm{a}}$ & $17.00 \pm 2.52^{\mathrm{a}}$ & $25.00 \pm 5.13^{\mathrm{a}}$ & $34.67 \pm 4.26^{\mathrm{a}}$ \\
\hline $\mathrm{T} 2$ & $17.33 \pm 6.36^{\mathrm{a}}$ & $18.00 \pm 3.00^{\mathrm{a}}$ & $18.33 \pm 1.67^{\mathrm{a}}$ & $20.67 \pm 5.27^{\mathrm{a}}$ & $7.33 \pm 0.33^{\mathrm{a}}$ & $12.00 \pm 2.08^{\mathrm{a}}$ & $17.67 \pm 1.45^{\mathrm{a}}$ & $33.67 \pm 3.48^{\mathrm{a}}$ \\
\hline $\mathrm{T} 3$ & $11.00 \pm 2.65^{\mathrm{a}}$ & $14.00 \pm 1.00^{\mathrm{a}}$ & $12.00 \pm 3.06^{\mathrm{a}}$ & $15.67 \pm 2.33^{\mathrm{a}}$ & $8.00 \pm 1.53^{\mathrm{a}}$ & $13.00 \pm 2.65^{\mathrm{a}}$ & $19.00 \pm 4.04^{\mathrm{a}}$ & $25.67 \pm 4.84^{\mathrm{a}}$ \\
\hline $\mathrm{T} 4$ & $6.00 \pm 0.00^{\mathrm{a}}$ & $6.67 \pm 0.67^{\mathrm{a}}$ & $7.33 \pm 0.67^{\mathrm{a}}$ & $8.67 \pm 1.76^{\mathrm{a}}$ & $9.67 \pm 1.20^{\mathrm{a}}$ & $9.67 \pm 1.76^{\mathrm{a}}$ & $12.33 \pm 1.86^{\mathrm{a}}$ & $18.33 \pm 2.60^{\mathrm{a}}$ \\
\hline
\end{tabular}

Values along the same column with the same letters are not significantly different at $\mathrm{p}<0.05$

Table III. Stem length $(\mathrm{cm})$ of variety NGB 00931 treated with industrial effluents

\begin{tabular}{|c|c|c|c|c|c|c|c|c|}
\hline \multirow{2}{*}{$\begin{array}{c}\text { Treatment } \\
\text { /week }\end{array}$} & \multicolumn{4}{|c|}{ Peace Standard Pharmaceutical effluent } & \multicolumn{4}{|c|}{ Global Soap \& Detergent Industry effluent } \\
\hline & Week 1 & Week 2 & Week 3 & Week 4 & Week 1 & Week 2 & Week 3 & Week 4 \\
\hline T0 & $15.67 \pm 2.19^{\mathrm{a}}$ & $8.00 \pm .53^{\mathrm{a}}$ & $21.67 \pm 2.19^{\mathrm{a}}$ & $33.67 \pm 3.29^{\mathrm{a}}$ & $10.00 \pm 1.53^{\mathrm{a}}$ & $16.00 \pm 3.51^{\mathrm{a}}$ & $24.33 \pm 6.89^{\mathrm{a}}$ & $37.33 \pm 10.91^{\mathrm{a}}$ \\
\hline $\mathrm{T} 1$ & $9.33 \pm 2.40^{\mathrm{b}}$ & $10.00 \pm 1.53^{\mathrm{a}}$ & $15.67 \pm 5.67^{\mathrm{ab}}$ & $29.33 \pm 10.40^{\mathrm{ab}}$ & $10.33 \pm 0.88^{\mathrm{a}}$ & $17.00 \pm 2.52^{\mathrm{a}}$ & $25.00 \pm 5.13^{\mathrm{a}}$ & $34.67 \pm 4.26^{\mathrm{a}}$ \\
\hline $\mathrm{T} 2$ & $13.33 \pm 1.20^{\mathrm{ab}}$ & $10.33 \pm 0.88^{\mathrm{a}}$ & $15.00 \pm 2.52^{\mathrm{ab}}$ & $24.67 \pm 3.18^{\mathrm{ab}}$ & $7.33 \pm 0.33^{\mathrm{a}}$ & $12.00 \pm 2.08^{\mathrm{a}}$ & $17.67 \pm 1.45^{\mathrm{a}}$ & $33.67 \pm 3.48^{\mathrm{a}}$ \\
\hline $\mathrm{T} 3$ & $9.67 \pm 0.88^{b}$ & $6.67 \pm 1.20^{\mathrm{a}}$ & $11.00 \pm 1.00^{\mathrm{ab}}$ & $17.00 \pm 1.53^{\mathrm{ab}}$ & $8.00 \pm 1.53^{\mathrm{a}}$ & $13.00 \pm 2.65^{\mathrm{a}}$ & $19.00 \pm 4.04^{\mathrm{a}}$ & $25.67 \pm 4.84^{\mathrm{a}}$ \\
\hline $\mathrm{T} 4$ & $8.67 \pm 0.88^{b}$ & $7.33 \pm 0.33^{a}$ & $8.67 \pm 4.67^{b}$ & $9.00 \pm 9.00^{\mathrm{b}}$ & $6.67 \pm 1.20^{\mathrm{a}}$ & $9.67 \pm 1.76^{\mathrm{a}}$ & $12.33 \pm 1.86^{\mathrm{a}}$ & $18.33 \pm 2.60^{\mathrm{a}}$ \\
\hline
\end{tabular}

Values along the same column with the same letters are not significantly different at $\mathrm{p}<0.05$

Table IV. Leaf size (cm) of variety NGB 00937 treated with industrial effluents

\begin{tabular}{|c|c|c|c|c|c|c|c|c|}
\hline \multirow{2}{*}{$\begin{array}{l}\text { Treatment } \\
\text { /week }\end{array}$} & \multicolumn{4}{|c|}{ Peace Standard Pharmaceutical effluent } & \multicolumn{4}{|c|}{ Global Soap \& Detergent Industry effluent } \\
\hline & Week 1 & Week 2 & Week 3 & Week 4 & Week 1 & Week 2 & Week 3 & Week 4 \\
\hline T0 & $7.33 \pm 0.67^{\mathrm{a}}$ & $8.00 \pm 2.00^{\mathrm{a}}$ & $11.33 \pm 3.33^{\mathrm{a}}$ & $18.67 \pm 8.74^{\mathrm{a}}$ & $13.33 \pm 2.40^{\mathrm{a}}$ & $14.33 \pm 2.33^{\mathrm{a}}$ & $13.33 \pm 0.88^{\mathrm{a}}$ & $25.33 \pm 8.99^{\mathrm{a}}$ \\
\hline $\mathrm{T} 1$ & $8.67 \pm 1.76$ & $11.67 \pm 2.03^{\mathrm{a}}$ & $12.67 \pm 2.91^{\mathrm{a}}$ & $18.67 \pm 3.38^{a}$ & $9.67 \pm 2.73^{\mathrm{a}}$ & $12.00 \pm 3.00^{\mathrm{a}}$ & $8.00 \pm 1.15^{\mathrm{a}}$ & $15.00 \pm 6.25^{\mathrm{a}}$ \\
\hline $\mathrm{T} 2$ & $9.00 \pm 3.00^{\mathrm{a}}$ & $12.67 \pm 2.33^{\mathrm{a}}$ & $8.00 \pm 1.15^{\mathrm{a}}$ & $13.00 \pm 4.36^{\mathrm{a}}$ & $15.67 \pm 4.63^{\mathrm{a}}$ & $14.67 \pm 3.76^{\mathrm{a}}$ & $15.00 \pm 5.20^{\mathrm{a}}$ & $14.00 \pm 5.29^{\mathrm{a}}$ \\
\hline $\mathrm{T} 3$ & $11.00 \pm 2.65^{\mathrm{a}}$ & $12.00 \pm 3.00^{\mathrm{a}}$ & $9.67 \pm 2.73^{a}$ & $10.00 \pm 2.00^{\mathrm{a}}$ & $9.00 \pm 3.00^{\mathrm{a}}$ & $9.00 \pm 3.00^{\mathrm{a}}$ & $9.67 \pm 2.73^{\mathrm{a}}$ & $8.00 \pm 3.61^{\mathrm{a}}$ \\
\hline $\mathrm{T} 4$ & $5.67 \pm 4.70^{\mathrm{a}}$ & $9.33 \pm 2.85^{\mathrm{a}}$ & $7.00 \pm 4.36^{\mathrm{a}}$ & $5.33 \pm 3.53^{\mathrm{a}}$ & $7.33 \pm 2.91^{\mathrm{a}}$ & $6.67 \pm 0.67^{\mathrm{a}}$ & $6.67 \pm 2.33^{\mathrm{a}}$ & $6.67 \pm 0.67^{\mathrm{a}}$ \\
\hline
\end{tabular}

Values along the same column with the same letters are not significantly different at $\mathrm{p}<0.05$

Table V. Stem length (cm) of variety NGB 00937 treated with industrial effluents

\begin{tabular}{|c|c|c|c|c|c|c|c|c|}
\hline \multirow{2}{*}{$\begin{array}{l}\text { Treatment } \\
\text { /week }\end{array}$} & \multicolumn{4}{|c|}{ Peace Standard Pharmaceutical effluent } & \multicolumn{4}{|c|}{ Global Soap \& Detergent Industry effluent } \\
\hline & Week 1 & Week 2 & Week 3 & Week 4 & Week 1 & Week 2 & Week 3 & Week 4 \\
\hline T0 & $6.83 \pm 0.17^{\mathrm{a}}$ & $11.00 \pm 0.58^{\mathrm{a}}$ & $15.00 \pm 0.00^{\mathrm{a}}$ & $26.33 \pm 1.76^{\mathrm{a}}$ & $3.67 \pm 1.20^{\mathrm{a}}$ & $12.33 \pm 1.33^{\mathrm{a}}$ & $17.67 \pm 1.76^{\mathrm{ab}}$ & $29.67 \pm 2.91^{\mathrm{a}}$ \\
\hline $\mathrm{T} 1$ & $6.00 \pm 1.15^{\mathrm{a}}$ & $9.67 \pm 1.45^{\mathrm{a}}$ & $13.67 \pm 1.45^{\mathrm{a}}$ & $23.33 \pm 0.33^{\mathrm{a}}$ & $2.33 \pm 0.33^{\mathrm{a}}$ & $10.33 \pm 2.43^{\mathrm{a}}$ & $18.33 \pm 3.53^{\mathrm{a}}$ & $24.67 \pm 5.17^{\mathrm{ab}}$ \\
\hline $\mathrm{T} 2$ & $5.83 \pm 0.44^{\mathrm{a}}$ & $11.00 \pm 1.53^{\mathrm{a}}$ & $16.00 \pm 2.65^{\mathrm{a}}$ & $22.33 \pm 2.73^{\mathrm{a}}$ & $3.00 \pm 0.58^{\mathrm{a}}$ & $11.67 \pm 1.76^{\mathrm{a}}$ & $15.67 \pm 1.45^{\mathrm{ab}}$ & $24.00 \pm 3.61^{\mathrm{ab}}$ \\
\hline T3 & $6.50 \pm 0.76^{\mathrm{a}}$ & $9.33 \pm 0.88^{\mathrm{a}}$ & $14.00 \pm 1.00^{\mathrm{a}}$ & $22.00 \pm 2.52^{\mathrm{a}}$ & $2.67 \pm 0.33^{\mathrm{a}}$ & $9.67 \pm 0.33^{\mathrm{a}}$ & $16.33 \pm 1.33^{\mathrm{ab}}$ & $23.67 \pm 2.96^{\mathrm{ab}}$ \\
\hline $\mathrm{T} 4$ & $5.67 \pm 2.96^{\mathrm{a}}$ & $11.67 \pm 1.20^{\mathrm{a}}$ & $10.67 \pm 5.61^{\mathrm{a}}$ & $15.33 \pm 8.19^{\mathrm{a}}$ & $2.00 \pm 0.58^{\mathrm{a}}$ & $7.67 \pm 0.33^{\mathrm{a}}$ & $10.33 \pm 1.86^{\mathrm{b}}$ & $15.33 \pm 3.28^{b}$ \\
\hline p-value & 0.977 & 0.610 & 0.747 & 0.467 & 0.509 & 0.266 & 0.144 & 0.177 \\
\hline
\end{tabular}

Values along the same column with the same letters are not significantly different at $\mathrm{p}<0.05$

Table VI. Leaf size (cm) of variety NGB 00939 treated with industrial effluents

\begin{tabular}{|c|c|c|c|c|c|c|c|c|}
\hline \multirow{2}{*}{$\begin{array}{c}\text { Treatment } \\
\text { /week }\end{array}$} & \multicolumn{4}{|c|}{ Peace Standard Pharmaceutical effluent } & \multicolumn{4}{|c|}{ Global Soap \& Detergent Industry effluent } \\
\hline & Week 1 & Week 2 & Week 3 & Week 4 & Week 1 & Week 2 & Week 3 & Week 4 \\
\hline T0 & $7.33 \pm 0.67^{\mathrm{a}}$ & $8.67 \pm 1.76^{\mathrm{a}}$ & $10.33 \pm 2.60^{\mathrm{a}}$ & $12.33 \pm 3.18^{\mathrm{a}}$ & $6.33 \pm 0.67^{\mathrm{a}}$ & $11.00 \pm 0.00^{\mathrm{ab}}$ & $19.00 \pm 0.58^{\mathrm{ab}}$ & $29.67 \pm 4.41^{\mathrm{a}}$ \\
\hline $\mathrm{T} 1$ & $9.33 \pm 1.33^{\mathrm{a}}$ & $15.00 \pm 0.00^{\mathrm{a}}$ & $15.00 \pm 0.00^{\mathrm{a}}$ & $12.33 \pm 1.45^{\mathrm{a}}$ & $5.33 \pm 0.33^{\mathrm{a}}$ & $9.33 \pm 0.33^{b}$ & $13.67 \pm 1.76^{\mathrm{c}}$ & $24.00 \pm 4.93^{\mathrm{a}}$ \\
\hline $\mathrm{T} 2$ & $9.33 \pm 1.33^{\mathrm{a}}$ & $8.67 \pm 0.67^{\mathrm{a}}$ & $10.00 \pm 2.65^{\mathrm{a}}$ & $12.00 \pm 4.16^{\mathrm{a}}$ & $8.67 \pm 1.76^{\mathrm{ab}}$ & $2.33 \pm 0.33^{\mathrm{a}}$ & $10.67 \pm 1.33^{\mathrm{a}}$ & $21.00 \pm 4.58^{\mathrm{a}}$ \\
\hline $\mathrm{T} 3$ & $11.00 \pm 2.65^{\mathrm{a}}$ & $11.00 \pm 2.65^{\mathrm{a}}$ & $11.67 \pm 1.67^{\mathrm{a}}$ & $10.00 \pm 5.29^{\mathrm{a}}$ & $12.00 \pm 0.00^{\mathrm{a}}$ & $2.67 \pm 0.33^{\mathrm{a}}$ & $11.67 \pm 2.03^{\mathrm{a}}$ & $15.00 \pm 1.73^{\mathrm{ab}}$ \\
\hline $\mathrm{T} 4$ & $6.00 \pm 1.15^{\mathrm{a}}$ & $9.00 \pm 3.00^{\mathrm{a}}$ & $7.67 \pm 3.84^{\mathrm{a}}$ & $6.00 \pm 3.00^{\mathrm{a}}$ & $6.67 \pm 0.67^{b}$ & $2.00 \pm 0.00^{\mathrm{a}}$ & $6.67 \pm 0.67^{\mathrm{a}}$ & $11.33 \pm 1.76^{b}$ \\
\hline
\end{tabular}

Values along the same column with the same letters are not significantly different at $\mathrm{p}<0.05$ 
Table VII. Stem length $(\mathrm{cm})$ of variety NGB 00939 treated with industrial effluent

\begin{tabular}{|c|c|c|c|c|c|c|c|c|}
\hline \multirow{2}{*}{$\begin{array}{l}\text { Treatment } \\
\text { /week }\end{array}$} & \multicolumn{4}{|c|}{ Peace Standard Pharmaceutical effluent } & \multicolumn{4}{|c|}{ Global Soap \& Detergent Industry effluent } \\
\hline & Week 1 & Week 2 & Week 3 & Week 4 & Week 1 & & & \\
\hline T0 & $5.33 \pm 0.33^{\mathrm{a}}$ & $9.00 \pm 1.00^{\mathrm{a}}$ & $14.00 \pm 2.08^{\mathrm{a}}$ & $27.00 \pm 2.65^{\mathrm{a}}$ & $6.33 \pm 0.33^{\mathrm{a}}$ & $12.00 \pm 0.00^{\mathrm{a}}$ & $21.67 \pm 2.67^{\mathrm{a}}$ & $31.33 \pm 1.67^{\mathrm{a}}$ \\
\hline $\mathrm{T} 1$ & $5.67 \pm 0.67^{\mathrm{a}}$ & $8.33 \pm 1.76^{\mathrm{a}}$ & $14.00 \pm 1.53^{\mathrm{a}}$ & $21.33 \pm 4.10^{\mathrm{a}}$ & $5.33 \pm 0.33^{\mathrm{a}}$ & $12.00 \pm 0.00^{\mathrm{a}}$ & $21.67 \pm 2.67^{\mathrm{a}}$ & $31.33 \pm 1.67^{\mathrm{a}}$ \\
\hline $\mathrm{T} 2$ & $5.33 \pm 0.67^{\mathrm{a}}$ & $8.67 \pm 1.76^{\mathrm{a}}$ & $14.33 \pm 1.45^{\mathrm{a}}$ & $21.00 \pm 10.82^{\mathrm{a}}$ & $6.33 \pm 0.67^{\mathrm{a}}$ & $11.00 \pm 0.00^{\mathrm{ab}}$ & $19.00 \pm 0.58^{\mathrm{ab}}$ & $29.67 \pm 4.41^{\mathrm{a}}$ \\
\hline $\mathrm{T} 3$ & $4.67 \pm 0.33^{\mathrm{a}}$ & $9.67 \pm 3.18^{\mathrm{a}}$ & $14.67 \pm 7.02^{\mathrm{a}}$ & $19.00 \pm 7.09^{\mathrm{a}}$ & $5.33 \pm 1.33^{\mathrm{a}}$ & $9.33 \pm 0.67^{b}$ & $13.67 \pm 1.76^{\mathrm{c}}$ & $24.00 \pm 4.93^{\mathrm{a}}$ \\
\hline $\mathrm{T} 4$ & $5.33 \pm 0.33^{\mathrm{a}}$ & $11.33 \pm 1.86^{\mathrm{a}}$ & $12.67 \pm 1.76^{\mathrm{a}}$ & $13.67 \pm 2.73^{\mathrm{a}}$ & $5.67 \pm 0.88^{\mathrm{a}}$ & $9.67 \pm 1.33^{\mathrm{b}}$ & $13.00 \pm 1.00^{\mathrm{c}}$ & $21.67 \pm 0.88^{\mathrm{a}}$ \\
\hline $\mathrm{p}$-value & 0.707 & 0.845 & 0.996 & 0.684 & 0.807 & 0.071 & 0.013 & 0.241 \\
\hline
\end{tabular}

Values along the same column with the same letters are not significantly different at $\mathrm{p}<0.05$

Table VIII. Leaf epidermal parameters of the three varieties of Sesamum indicum treated with industrial effluent

\begin{tabular}{|c|c|c|c|c|c|c|c|c|c|c|c|c|}
\hline \multirow{3}{*}{$\begin{array}{l}\text { Leaf epidermal } \\
\text { parameters }\end{array}$} & \multicolumn{6}{|c|}{ Peace Standard Pharmaceutical treatment } & \multicolumn{6}{|c|}{ Global Soap \& Detergent Industry treatment } \\
\hline & \multicolumn{2}{|c|}{ NGB 00931} & \multicolumn{2}{|c|}{ NGB 00937} & \multicolumn{2}{|c|}{ NGB 00939} & \multicolumn{2}{|c|}{ NGB 00931} & \multicolumn{2}{|c|}{ NGB 00937} & \multicolumn{2}{|c|}{ NGB 00939} \\
\hline & PCV1 & PEV1 & $\mathrm{PCV} 2$ & PEV2 & PCV3 & PEV3 & GCV1 & GEV1 & GCV2 & GEV2 & GCV3 & GEV3 \\
\hline Stomatal size $(\mu \mathrm{m})$ & 112 & 120 & 116 & 124 & 102 & 118 & 116 & 96 & 102 & 77 & 96 & 66 \\
\hline Trichome size $(\mu \mathrm{m})$ & 1570 & 1680 & 1406 & 1792 & 1518 & 1890 & 1530 & 1492 & 1392 & 1280 & 1420 & 964 \\
\hline Number of epidermal cells & 30 & 78 & 42 & 89 & 50 & 98 & 40 & 98 & 56 & 70 & 68 & 52 \\
\hline Stomatal index $(\%)$ & 44.44 & 22.77 & 34.38 & 21.93 & 34.21 & 19.67 & 38.46 & 19.67 & 29.11 & 27.10 & 28.42 & 32.47 \\
\hline Trichome index (\%) & 3.23 & 2.50 & 4.55 & 1.10 & 3.85 & 1.01 & 4.76 & 1.01 & 5.10 & 1.40 & 2.86 & 3.70 \\
\hline Trichome density $\left(\mathrm{mm}^{-2}\right)$ & 6.58 & 13.16 & 13.16 & 6.58 & 13.16 & 6.58 & 13.16 & 6.58 & 19.74 & 6.58 & 13.16 & 13.16 \\
\hline
\end{tabular}

Keys: Sesamum varieties = NGB 00931, NGB 00937, NGB 00939

$\mathrm{PCV}=$ peace control, $\mathrm{PEV}=$ peace experimental, $\mathrm{GCV}=$ global control, $\mathrm{GEV}=$ global experimental

characters of these effluents is shown in the tables. Seed inhibitory nature of effluents of the two industries used in this study is in line with studies conducted by Panaskar and Pawar (2011) which showed that textile effluents were not inhibitory at low concentrations but with the increase in concentration growth of seedlings was affected. Rodosevich et al., (1997) considered seed germination a critical step as it ensures reproduction and controls the dynamics of plant population as well as probable crop productivity. In this present study, all sesame varieties decreased in leaf size and stem length with increasing concentration of effluents from the industrial effluents of the two industries. However, at low concentrations, leaf size and stem length increased. These may be due to the facts that the effluent is rich in inorganic nutrients, which may have beneficial effects on seedlings. Augusthy and Sherin (2001) indicated that length of root system and number of lateral roots of Vigna radiate increased by low concentrations of effluent. We may relate the reduction in leaf size and stem lengths with the elevated amounts of total dissolved solids at higher concentrations. This could also be related to the fact that some of the nutrients present in the effluents are essentials but at above particular concentration, they become hazardous.

Leaf epidermis of $S$. indicum showed varied responses to the various concentrations of the effluents. There was no difference in structures of the anticlinal wall and trichome of the leaf epidermis in all the treatments. This has also been reported by Omosun et al., (2008) in A. hybridus irrigated with crude oil. The toxic effects of the effluents were observed from the $25 \%-100 \%$ effluent concentrations in the form of reduction of the trichome density and number of epidermal cells at the adaxial surface. The decreased stomatal size (on both leaf surfaces) in all the treatments aside the control is an indication of $S$. indicum survival strategy in the presence of pollutants from the effluents. Reduced stomatal size helps in increasing the rate of photosynthesis without excessive transpiration according to Melo et al., (2007). This also assist in lowering the rate of transpiration and reduce stomatal conductance in the presence of stress of chemical pollutants as observed in the leaves of Cenchrus cellaris by Vijayakumar and Udayasoorian (2007). This was also reported by Abdulrahaman (2009); Abdulrahaman and Oladele (2012) in which stomatal size of some ornamental and xerophytic plants were reduced which later translated to reduce rate of transpiration. Noman et al., (2012) affirmed that stomatal size modification is an indication of the presence of heavy metal toxicity which could prove that the effluents may have contained toxic heavy metal. Also on the other hands, the high influence of the effluent especially that of the Peace Standard Pharmaceutical Industry on the leaf epidermal features such as stomatal density, stomatal index, stomatal size, trichome density, trichome index, trichome size and 
number of epidermal cells supposed to be positive influence on such physiological parameters such as photosynthesis and high rate of carbondioxide, and transpiration. Improvement in the photosynthetic activities of plants will surely lead to high yield.

In conclusion, both effluents played a role in the germination of the three Sesame varieties by increasing growth parameters at low concentrations. However, higher concentrations caused a decrease in growth parameters may be hazardous to the plant and may translate to low biomass production. Such high concentrations of effluents are thus constituents of water or soil pollution. It is evidently clear from the study that low concentration of these effluents can be non-toxic to vegetable growth.

\section{References}

Abdulrahaman AA (2009), Morphological and epidermal adaptations to water stress in some ornamental plant species, Ph.D Thesis, University of Ilorin, Ilorin, Nigeria. pp 71- 101.

Abdulrahaman AA and Oladele FA (2012), Anatomical basis for optimal use of water for maintenance of three xerophytic plants, Notulae Scientia Biologicae 4(2): 53-58.

Augusthy PO and Sherin MA (2001), Effect of factory effluents on seed germination and seedling growth of Vigna radiate L, J. Env. Res. 22(92): 137-139.

Dilcher DL (1974), Approaches to the identification of angiosperm leaf remains, Botanical Review 40: 1-157.

Fathi A A, El-Shaheed AM, Shoulkany MA, Ibraheim HA and Abdel Rahman OM (2008), Response of Nile water phytoplankton to the toxicity cobalt, copper and zinc, Research Journal of Environmental Toxicology 2: $67-76$.

Franco C (1939), Relation between chromosome number and stomata in Coffea, Botanic Gazette 100: 817-818.

Hussain F, Malik SA, Athar M, Bashir N, Younis U, Hassan, MU and Mahmood S (2010), Effect of tannery effluents on seed germination and growth of two sunflower cultivars, Afr. J. Biotech. 9(32): 51135120 .

Irshad A, Ali S and Jan MR (1997), Physicochemical studies of industrial pollutants. Proccedings of the NSMTCC on Environmental Pollution, February 2426, 1997, Islamabad, Pakistan, pp 1-96.

Kovacic S and Nikolic T (2005), Relations between Betula pendula Roth (Betulacae) leaf morphology and environmental factors in five regions of Croatia. Acta Biol. Cracoviensia 47: 7- 13.

Lenwood H and Dennis B (2005), An integrated case study for evaluating the impacts of an oil refinery effluent on Aquatic Biota in the Delaware River: Introduction, study Approach and objectives, Human and Ecological Risk Assessment 11(4): 647-656.

Melo HC, Castro EM, Soares AM, Melo LA and Alves JD (2007), Anatomical and physiological alterations in Setaria anceps stapf ex Massey and Paspalm paniculatum under water deficit conditions, Hoehnea 34: 145-153.

Noman A, Hammed M, Ali Q and Aqeel M (2012), Foliar tissue architectural diversity among three species of genus Hibiscus for better adaptability under industrial environment, Int J. Environ Sci. 2(4): 2212-2222.

Obiremi EO and Oladele FA (2001), Water-conserving stomatal system in selected Citrus species, South African Journal of Botany 67: 258-260.

Omosun G, Markcon AA and Mbanasor O (2008), Growth and anatomy of Amaranthus hybridus as affected by different crude oil concentrations, Am-Euras $J$ Sci. Res. 3(1): 7074-7082.

Panasker DB and Pawar RS (2011), Effect of textile mill effluent on growth of Vigna unguiculata and Pisum sativum seedlings, Indian J. Sci. Technol. 4(3): 266272.

Rodosevich S, Holt J and Ghersa C (1997), In: Weed Ecology, Implications for Management, Wiley Publishers, New York.

Schofield RK and Taylor AW (1955), Measurements of the activities of bases in soils, Journal of Soil Science 6(1): $137-146$.

Vijayakumar PS and Udayasoorian C (2007), Anatomical response of Cenchrus celiaris to the paperboard effluent irrigation, World Journal of Agricultural Science 3(4): 553-557.

Received: 22 July 2015; Revised: 11 July 2016;

Accepted: 28 July 2016. 